\title{
Istanbul Bibliography 2019
}

\section{Compiled by Muhammed Zinciroğlu}

Abo Shanab, El-Sayed S., and Ibrahim W. Hassanein. "Paintings of Turkish Religious Structures in Istanbul through Some Works of the English Orientalist Painter Thomas Alloum Mid 13th AH/19th AD Century." Shedet 5 (2018): 211-223.

Acar, Damla. "Method for Conservation of Late 19th Century Timber Framed Buildings in Istanbul: Post-Earthquake House of Kemaleddin Efendi in Dolmabahçe Palace.” Eurasian Journal of Social Sciences 6, no. 4 (2018): 14-36.

Acıduman, Ahmet, Serap Şahinoğlu, and Önder Illgili. "Kadına Yönelik Şiddet: İstanbul Şer î Mahkeme Sicillerine Göre." Lokman Hekim Dergisi 9, no. 2 (2019): 236-255.

Adalet, Begüm. Hotels and Highways: The Construction of Modernization Theory in Cold War Turkey. Standford: Stanford University Press, 2018. Reviewed in YILLIK: Annual of Istanbul Studies 1 (2019), by Mehmet Ekinci.

Adıgüzel, Hatice. "Bir Tasarımın İzinde: Yeni Bulgular Işığında Raimondo D’Aronco'nun Illk İstanbul Projesi Dersaadet Ziraat ve Sanayi Sergi-i Umumisi." METU Journal of the Faculty of Architecture 36, no. 1 (2019): 157-182.

Afyoncu, Erhan, and Uğur Demir. "Mukaddes Emanetlerin İstanbul'a İntikali.” Türk Kültürü İncelemeleri Dergisi 20, no. 40 (Spring 2019): 143-186.

Ağaoğlu, Mert. "Arşiv Belgeleri Işı̆̆ında Mimarbaşı El-Hac İbrahim Ağa'nın Baş Mimarlığı Döneminde İstanbul'daki İmar Faaliyetleri." Ekev Akademi Dergisi 22, no. 73 (Winter 2018): 1-24.

Ağır, Aygül. "Francesco Sansovino ve 'Türklerin Kökeninin ve İmparatorluğunun Evrensel Tarihi' Kitabında Kent, Mimarlık ve Gündelik Yaşam.” Istanbul Araştırmaları Yıllı̆̆ı 7 (2018): 67-92.

Akbulut, Ayşe, and Özlem Özçevik. "Investigation of the Relationship between Environmental Sustainability and Gated Communities in Beykoz, Istanbul." Ömer Halisdemir Üniversitesi Mühendislik Bilimleri Dergisi 8, no. 2 (2019): 1265-1276.

Akcan, Esra. “Kronizm Çağında İstanbul ve Mimarlık Etkisi.” Arradamento Mimarlık 330 (April 2019): 84-93. Akışık-Karakullukçu, Aslıhan. "From 'Bounteous Flux of Matter' to Hellenic City: Late Byzantine Representations of Constantinople and the Western Audience." In Receptions of Hellenism in Early Modern Europe, edited by Natasha Constantinidou and Han Lamers, 145-172. Leiden: Brill, 2019.

Akiba, Jun. "Girls Are Also People of the Holy Qur'an': Girls' Schools and Female Teachers in Pre-Tanzimat Istanbul." Hawwa 17 (2019): 21-54.

Akyıl Erentürk, Sema, Sevilay Hacıyakupoğlu, Rüveyda K. Ileri, and Neslihan Yanıkömer. "Chemical Patterns in Sediments of Ancient Theodosius Harbour (Istanbul)." Journal of Soils and Sediments 18 (2018): 3415-3423.

Anagnostou-Laoutides, Eva. "Herakles in Byzantium: A (Neo) Platonic Perspective." In Herakles Inside and Outside the Church: From the First Apologists to the End of the Quattrocento, edited by Arlene Allan, Emma Stafford, and Eva Anagnostou-Laoutides, 201-236. Leiden: Brill, 2019.

Anastassiadou-Dumont, Méropi. "Sacred Spaces in a Holy City. Crossing Religious Boundaries in Istanbul at the Turn of the Twenty-First Century." Entangled Religions 9 (2019):34-56.

And, Metin. Ottoman Figurative Arts 2: Bazaar Painters. Edited by Sabri Koz and Tülün Değirmenci. Istanbul: Yapı Kredi Yayınları, 2018.

Aras, Lerzan. "Neo-Liberal Touches to the Town: Reading Life in Istanbul Ataşehir through Bourdivin Theory.” Dokuz Eylül Üniversitesi Sosyal Bilimler Enstitüsü Dergisi 20, no. 3 (2018): 381-396.

Atmaca Çetin, Hande, Zeynep Tuna Ultav, and Funda Uz. "Reflections of the İstanbul Hilton Hotel on Mid-century Hotel Buildings in Turkey." Art-Sanat 12 (July 2019): 57-88.

Avkovan, Emine Nazan. “ístanbul Tatavla/Kurtuluş Semti’nin Kültürel ve Mimari Kimlik Değişimi.” MA thesis, Maltepe University, 2019. 
Aykaç, Pınar. "Musealisation as a Strategy for the Reconstruction of an Idealised Ottoman Past: Istanbul's Sultanahmet District as a 'Museum-Quarter.'” International Journal of Heritage Studies 25, no. 2 (2019): 160-77.

Aysal Cin, Ulaş Duygu. "Electrification of Istanbul (1878-1923)." PhD diss., Bilkent University, 2019.

Balaban Uçar, Mualla, and Oktay Gönültaş. "Volatile Compounds of Archaeological Wood from the Ancient Harbor of Thedosius in Istanbul." European Journal of Wood and Wood Products 77, no. 3 (May 2019): 475-481.

Balsoy, Gülhan. "Haseki Women's Hospital and the Female Destitute of Nineteenth-Century Istanbul." Middle Eastern Studies 55, no. 3 (2019): 289-300.

Barsanti, Claudia, and Alessandra Guiglia. "Spolia in Constantinople's Hagia Sophia from the Age of Justinian to the Ottoman Period: The Phenomenon of Multilayered Reuse." In Spolia Reincarnated: Afterlives of Objects, Materials, and Spaces in Anatolia from Antiquity to the Ottoman Era, edited by Ivana Jevtić and Suzan Yalman, 97-123. Istanbul: ANAMED, 2018. Reviewed in YILLIK: Annual of Istanbul Studies 1 (2019), by Emily Neumeier.

Baş Bütüner, Funda. "Urban Fissure: The Spatial Manifestation of the Istanbul Land Walls and Mural Zone." METU Journal of the Faculty of Architecture 36, no. 1 (2019): 223-250.

Baykal, Erol A. F. The Ottoman Press (1908-1923). Leiden: Brill, 2019.

Bayrak, Sevince. Bir Meydan Öyküsü: Beyazıt (1914-1964). Istanbul: Türkiye İş Bankası Kültür Yayınları, 2019.

Bayraktar-Tellan, Elif, and Hasan Çolak. The Orthodox Church as an Ottoman Institution. A Study of Early Modern Patriarchal Berats. Istanbul: The Isis Press, 2019.

Bazarova, Tatyana A. "Two Missions of Major Hieronymus Natalie to Istanbul: Diplomatic Contacts between Russia and the Ottoman Empire in 1715-1718." Science Journal of Volgograd State University. History. Area Studies. International Relations 24, no. 1 (2019): 84-97.

Becerikli, Sabri, and Muammer Demirel. "İstanbul Yüksek Öğretmen Okulunun Kısa Tarihçesi." Uluslararası Türkçe Edebiyat Kültür Eğitim Dergisi 8, no. 1 (2019): 603-631.

Belviranlı, Sena, and Nuran Kara Pilehvarian. "Ingiltere Veliahtı Prens Edward (Kral VII. Edward)'ın 1862 ve 1867 Yıllarındaki İstanbul Ziyaretleri ve Gezdiği Yapılar Çerçevesinde Osmanlı Teşrifatındaki Değişimler." Megaron 13, no. 4 (2018): 608-622.

Behar, Cem. Aşk Olmayınca Meşk Olmaz: Geleneksel Osmanlı/Türk Müziğinde Öğretim ve Intikal, genişletilmiş 7. baskı. Istanbul: Yapı Kredi Yayınları, 2019.

Benli, Gülhan, Alper Yiğitoğlu, and Y. Dolunay Yüksel. "The Use of Laser Scanning Technology to Survey Building Facades: A Case Study of Camlica Street, Beylerbeyi, Istanbul.” Online Journal of Art \& Design 7, no. 1 (January 2019): 220-230.

Berkmen, Naime Hülya, and Sirma Turgut. “Kentsel Dönüşüm Kıskacında ‘Bağdat Caddesi'” Megaron 14, Supplement 1 (2019): 155-166.

Bezgin, Niyazi Özgür. "Rediscovery of the Great Architect's Bridge: Mimar Sinan Bridge, Istanbul, Turkey.” Transportation Research Record (April 2019) doi.org/10.1177/0361198119835811.

Bianchi, Raffaella. "Istanbul Sounding Like Revolution: The Role of Music in the Gezi Park Occupy Movement.” Popular Music 37, no. 2 (May 2018): 212-36.

Billig, Noah. Istanbul : Informal Settlements and Generative Urbanism. London: Routledge, 2018.

Bodde, Anne Marije. "A Spatial Strategy for Refugee Integration in the Urban Environment: The Case of Istanbul." MA thesis, TU Delft, 2019.

Boeck, Elena. "Fantasy, Supremacy, Domes, and Dames: Charlemagne Goes to Constantinople." Byzantium in Dialogue with the Mediterranean, edited by Daniëlle Slootjes and Mariette Verhoeven, 142-161. Leiden: Brill, 2019.

Boleken, Zeki. “Topkapı Sarayı Revan Köşkü’nde Kullanılan Devşirme Malzemelerin Yeniden Değerlendirilmesi." İstanbul Araştırmaları Yıllı̆̆ı 7 (2018): 49-66.

Bonini Baraldi, Sara, Daniel David Shoup, and Luca Zan. "When Megaprojects Meet Archaeology: A Research Framework and Case Study from Yenikapi, Istanbul." International Journal of Cultural Policy 25, no. 4 (2019): 423-444.

Bornovalı, Sedat. "Hartmann Schedel'in İstanbul Görünümleri." Art-Sanat Dergisi 11 (January 2019): 13-46.

Boyar, Ebru. "The Late Ottoman Brothel in Istanbul: A Heterosexual Social Space for Homosocial 

182. Leiden: Brill, 2019.

Brummett, Palmira. "Censorship in Late Ottoman Istanbul: The Ordinary, The Extraordinary, The Visual." Journal of the Ottoman and Turkish Studies Association 5, no. 2 (Fall 2018): 75-98.

Busine, Aude. "The Dux and the Nun. Hagiography and the Cult of Artemios and Febronia in Constantinople." Dumbarton Oaks Papers 72 (2018): 93-111.

Byzantios, Skarlatos D. Constantinople: A Topographical, Archaeological \& Historical Description of the Celebrated Metropolis \& Her Environs on Both Sides of the Golden Horn \& the Bosphorus, from Most Ancient Times to the Present, Adorned with Many \& Diverse Illustrations, As Well As Topographical \& Chronological Tables Essential for Elucidating Byzantine History. Volume 1. Translated and edited by Haris Rigas, foreword by Stephanos Pesmazoglou. Istanbul: İstos, 2019. Reviewed in YILLIK: Annual of Istanbul Studies 1 (2019), by Firuzan Melike Sümertaş.

Can, Yeliz, Salih Tura and Esra Kudde. "Evaluation of the Preservation State of Historical Peninsula in Istanbul Based on Geospatial Data." International Archives of the Photogrammetry, Remote Sensing and Spatial Information Sciences, Volume XLII-2/W11 (2019): 353-357.

Cattelan, Vittorio. "The Italian Opera Culture in Constantinople during the Nineteenth Century." Annali Di Ca' Foscari: Serie Orientale 54, no. Supplemento (December 2018): 621-656.

Chrysos, Evangelos. "Rome and Constantinople in Confrontation: The Quarrel over the Validity of Photius's Ordination." In Byzantium in Dialogue with the Mediterranean, edited by Daniëlle Slootjes and Mariette Verhoeven, 24-46. Leiden: Brill, 2019.

Çalışlar, İzzeddin, ed. Batıya Açılan Pencere: Galatasaray Lisesinnin 150. Yıll / A Window to the West: The 150 Years of the Galatasaray Lycée. Istanbul: İstanbul Araştırmaları Enstitüsü, 2018.

Çetintaş, M. Burak. "Yeniçeri Zâbit Zümresi Başlıkları: Kalafat ve Çatal Kalafat Serpuşları Üzerine Bir Deneme." İstanbul Araştırmaları Yıllığı 7 (2018): 93-132.

Çelebi Gürkan, Ülkü, and Nuray Özaslan. "Dönüşen Kamusal Mekan: İstanbul-Göktürk Örneği.” Uluslararası Sosyal Araştırmalar Dergisi 12, no. 62 (February 2019): 490-504.

Çelebioğlu, Banu, and Uzay Yergün. "Pera Palace Hotel Construction Technology." Megaron 14, no. 1 (2019): 11-17.

Çiçek, Niyazi, and Nurhan Kabakulak. "Harf Devrimi'nin Ardından İstanbul Kitapçılarının Yaşadıkları Zorluklar Nedeniyle Hükümetten Yardım Talepleri.” Türkiyat Mecmuası 28, no. 2 (2018): 1-18.

Çiçekoğlu, Feride. "The Secular Army or the New Ottoman Fantasy? Negotiating Hegemonic Masculinity in the Image of İstanbul." In The Dubious Case of a Failed Coup, edited by Feride Çiçekoğlu and Ömer Turan, 91-121. Singapore: Palgrave Macmillan, 2019.

_. Isyankar Şehir: Gezi Sonrast İstanbul Filmlerinde Mahrem-İsyan. İstanbul: Metis, 2019.

Çiftçi, Yasemin. "XVI. Yüzyıl Osmanlı İstanbul'u Gayrimenkul Fiyat Serisi: İstanbul Kadı Sicilleri Işı̆̆ında." Journal of Life Economics 5, no. 1 (January 2018): 59-82.

Çoban, Bilge. "Türkiye'de İşsizlik Profili Bağlamında Suriyeli Gençlerin İstanbul İşgücü Piyasasına Katılım Sorunlar1." Çalısma ve Toplum 56, no. 1 (2018): 193-216.

Çobancaoğlu, Tülay, Koray Güler, and Gülce Güleycan Okyay. "İstanbul Tarihi Yarımada'da Ahşap Konut Mimarisinin Belgelenmesi: Geleneksel Haydar Mahallesi ve Koruma Sorunları.” METU Journal of the Faculty of Architecture 35, no. 1 (2018): 27-49.

Çulha, Ibrahim. "Türk Rum Mübadelesinde "Etabli” Sorunu, İstanbul'un Sınırları Konusundaki Anlaşmazlık ve Türkiye'nin İzlediği Politika.” Atatürk ve Türkiye Cumhuriyeti Tarih Dergisi 2, no. 4 (Winter 2019): 155-202.

Danış, Didem, and Dilara Nazlı. "A Faithful Alliance Between the Civil Society and the State: Actors and Mechanisms of Accommodating Syrian Refugees in Istanbul." International Migration 57, no. 2 (April 2019): 143-157.

Dark, Ken, and Jan Kostenec. Hagia Sophia in Context: An Archaeological Re-examination of the Cathedral of Byzantine Constantinople. Oxford: Oxbow Books, 2019.

De Zorzi, Giovanni. "Dervishes Ceremonies in Constantinople Described by Western Travellers and Painters between Sixteenth and Eighteenth Century.” Annali Di Ca' Foscari: Serie Orientale 55 (June 2019): 121-152.

Demirhan, Hilal. "Cultural Heritage Preservation Development in Turkey through Case Studies from 
Istanbul. A Different Perspective to Restoration." MA thesis, Politecnico Milano, 2019.

Deniz, Ayla, E. Murat Özgür, and Muhammet Öksüz. "Dini Mekanların Toplumsal Hafızaya Etkileri: İstanbul Aya Panteleymon Ortodoks Kilisesi Örneği." International Journal of Geography and Geography Education 39 (2019): 171-188.

Deniz, Ünsal. “İstanbul Radyosu'nun İlk Dönemindeki (1927) Müzik Yayınları.” Eurasian Journal of Music and Dance 14 (2019): 63-88.

Demirtiken, Elif. "Changing Profiles of Monastic Founders in Constantinople, From the Komnenoi to the Palaiologoi: The Case of the Theotokos Pammakaristos Monastery in Context." In Trends and Turning Points: Constructing the Late Antique and Byzantine World, edited by Matthew Kinloch and Alex MacFarlane, 266-286. Leiden: Brill, 2019.

Dikçınar Sel, Berna. "İstanbul Kıyılarında Farklı Toplumsal Yapılar ve Kıyı Ilişkileri.” Megaron 13, no. 3 (2018): 442-450.

Dinç, Güven. "Antalya Buğdayı İstanbul Fırınlarında: XIX. Yüzyıl Başlarında İstanbul'un Buğday İhtiyacının Karşılanmasında Antalya'nın Önemi.” Türkiyat Araştırmaları Enstitüsü Dergisi 65 (May 2019): 289-301.

Doğan, Cem. Osmanlı'da Cinselliğin Saklı Klyısı: II. Abdülhamid Dönemi ve Sonrast İstanbul'da Fuhuş, Frengi ve İktidar (1878-1922). İstanbul: Tarih Vakf1 Yurt Yayınları, 2019.

Dossey, Leslie. "Night in the Big City: Temporal Patterns in Antioch and Constantinople as Revealed by Chrysostom's Sermons." In Revisioning John Chrysostom, edited by Chris de Wet and Wendy Mayer, 698-732. Leiden: Brill, 2019.

Dursteler, Eric R. "Sex and Transcultural Connections in Early Modern Istanbul." Studi e Materiali Di Storia Delle Religioni 84, no. 2 (2018): 498-512.

Duru, Asl1. "A Walk down the Shore': A Visual Geography of Ordinary Violence in Istanbul." Environment and Planning D: Society and Space (July 2019). doi.org/10.1177\%2Fo263775819859362.

Durusoy Özmen, Elifnaz, and Mehmet Cengiz Can. "Conservation of the Land Walls Protection Area by Renewal (!): Evaluating the Spatial Effects of the Law No. 5366 through 'Zeytinburnu Culture Valley Project' of Istanbul." Megaron 13, no. 4 (2018): 505-520.

Eldem, Edhem. Mitler, Gerçekler ve Yöntem: Osmanlı Tarihinde Aklıma Takılanlar. Istanbul: Tarih Vakfı, 2018.

—. V. Murad'ın Oğlu Selahaddin Efendi'nin Evrak ve Yazıları I. Cilt: V. Murad ile Cleanthi Scalieri. Istanbul: İş Bankası Kültür Yayınları, 2019.

Eliçin, Yeşeren. "Refugee Crisis and Local Responses: An Assessment of Local Capacities to Deal with Migration Influxes in Istanbul." Hrvatska i komparativna javna uprava 18, no. 1 (2018): 73-99.

Endres, Clifford. Edouard Roditi ve İstanbul Avangardl. Translated by Selhan Savcigil. İstanbul: Kırmızı Kedi Kitabevi, 2018.

Erbaş, Adem Erdem. "İstanbul Metropoliten Alanı'nda 1980 Sonrası Kentsel Gelişme Dinamikleri ve İdari Coğrafyada Sınır Değişiklikleri.” Mehmet Akif Ersoy Üniversitesi İktisadi ve İdari Bilimler Fakültesi Dergisi 1, no. 5 (May 2018): 17-38.

Ercan, Hüseyin Onur. "Pasarofça Antlaşmasını Mübâdele İçin İstanbul'a Gelen Büyükelçi Damian Hugo von Virmont'un Raporu Hakkında." In Harp ve Sulh 30o. Yllında Pasarofça Antlaşması Sempozyumu Bildirileri, edited by Gültekin Yıldız, 141-149. İstanbul: MSÜ Yayınları, 2019.

Erdoğan, Nezih. "Early Cinema-Going and the Emergence of Film Culture: The First Pathé Cinema Theatre Opens in Istanbul (1908)." Participations Journal of Audience and Reception Studies 16, no. 1 (2019): 698-717.

Erek, Ayşe N., and Esra Almas. "Photographs, Memories, Monuments and Movements: Black and White Istanbul in the Work of Orhan Pamuk and Ara Güler." Comparative Studies in Modernism 14 (2019): 77-86.

Erek, Ayşe N., and Eszter Ganter. "Disappearing History: The Reinterpretation of Heritage in Saint Petersburg and in Istanbul." In Urban Heritage: Agents, Access, and Securitization, edited by Heike Oevermann and Eszter Gantner, 153-170. New York: Routledge, 2019.

Eryar, Değer, Hasan Tekgüç, and Şule Toktaş. "Does Migration Contribute to Women's Empowerment? Portrait of Urban Turkey and Istanbul.” Turkish Studies 20, no. 2 (2019): 200-221.

Esders, Stefan. "Procopius of Caesarea, the Lex Tricennalis, and the 'Time of the Vandals': Historiography, Law, and Political Debate in Mid-Sixth-Century Constantinople." Early Medieval Europe 27, no. 2 (May 2019): 195-225. 
Eyüpgiller, Kemal Kutgün, and Yeşim Yaşa. İstanbul Boğazı Kale ve Tabyaları. İstanbul: Kitabevi Yayınları, 2019.

Feldman, Walter. "Itri's 'Nühüft Sakil' in the Context of Ottoman Peşrevs of the Seventeenth Century." In Tuning the Past: Essays in Honour of Owen Wright, edited by Martin Stokes and Rachel Harris, 73-82. London: Ashgate, 2018.

—. "The Indian Style and the Ottoman Literary Canon." International Journal of Persian Literature 3, no. 1 (2018): 3-38.

Fetvac1, Emine. The Album of the World Emperor: Cross Cultural Collecting and the Art of Album Making in Seventeenth-Century Istanbul. Princeton: Princeton University Press, 2019.

- "Persian Aesthetics in Ottoman Albums." In Studying the Near and Middle East at the Institute for Advanced Study, Princeton, 1935-2018, edited by Sabine Schmidtke, 402-412. Piscataway: Gorgias Press, 2018.

F1çı, Burak. "The Conflagrations of Ottoman Istanbul in the Late 18th and Early 19th Centuries According to Ottoman and European Sources." MA thesis, Leiden University, 2019.

Gaul, Niels. "Zooming in on Constantinople: Introductory Notes on the Interplay of Center, Province and Periphery in the Tenth-Century Byzantine Empire." In Center, Province and Periphery in the Age of Constantine VII Porphyrogennetos : From De ceremoniis to De administrando imperio, edited by Niels Gaul, Volker Menze and Csanád Bálint, 1-21. Wiesbaden: Harrassowitz Verlag, 2018.

Genç, H. Deniz, and Merve Özdemirkiran-Embel. "Paradoxical Perceptions on Syrians' Forced Migration to Turkey: A Case Study of Istanbul Muhtars." Alternatif Politika 11, no. 1 (February 2019): 168-191.

Genoud, Alice. "The Politics of Greening the City: The Case of the Bostan of Kuzguncuk, Istanbul." Nature and Culture 13, no. 1 (March 2018): 69-92.

Girardelli, Paolo. "Landscape and Divine Justice: Archbishop Hilléreau's Perception and Patronage of Christian Architecture in Istanbul.” In Sacred Spaces and Urban Networks, edited by Suzan Yalman and Hilâl Uğurlu, 33-50. Istanbul: ANAMED, 2019.

Göker, Parisa, and Elmas Erdoğan. "The Restitution and Design Principles of Beylerbeyi Palace Gardens, Istanbul." Journal of History, Culture \& Art 7, no. 3 (2018): 60-78.

Göncü, Tuncay Cengiz. Dolmabahçe Sarayı: Inşa Süreci, Mekan ve Teşkilatı. Istanbul: İstanbul Araştırmaları Enstitüsü, 2019.

—_. "Abdülaziz Döneminde Yayımlanan Bir Yangın Tenbihnamesi Üzerine Bazı Tespitler.” İstanbul Araştırmalart Yıllığı 7 (2018): 159-172.

Göndiken, Özgür. "Philanthropy in Constantinopolitan Monasteries and their Financial Resources in the Palaiologan Period.” Ortaçağ Araştırmalar Dergisi 2, no. 1 (June 2019): 56-67.

Graf, Tobias P. "Stopping an Ottoman Spy in Late Sixteenth-Century Istanbul: David Ungnad, Markus Penckner, and Austrian-Habsburg Intelligence in the Ottoman Capital." In Rethinking Europe, edited by Gerhild Scholz Williams, Sigrun Haude and Christian Schneider, 173-193. Leiden: Brill | Rodopi, 2019.

Grigoryan, Irena. Armenian Labor Migrants in Istanbul: Reality Check. Istanbul: MiReKoc, 2018.

Gümüş, Müjde Dila. "Zincirlikuyu Kasrı'nda Vedad (Tek) Bey Tarafından Yusuf İzzeddin Efendi için Yapılan Mimari Düzenlemeler.” İstanbul Araştırmaları Yıllı̆̆ı 7 (2018): 137-146.

Günay, Onur, and Erdem Yörük. "Governing Ethnic Unrest: Political Islam and the Kurdish Conflict in Turkey." New Perspectives on Turkey 61 (2019): 9-43.

Günay, Onur. "In War and Peace: Shifting Narratives of Violence in Kurdish Istanbul." American Anthropologist 121, no. 3 (2019): 554-567.

Gür, Elmira Ayşe, and Yurdanur Dülgeroğlu Yüksel. "Analytical Investigation of Urban Housing Typologies in Twentieth Century Istanbul." International Journal of Architectural Research 13, no. 1 (2019): 93-111.

Gürgen, Gülseher. "An Evaluation on the Life of Prostitutes in the Late Ottoman Istanbul through the Novels of Ahmed Midhat Efendi and Hüseyin Rahmi Gürpınar." MA thesis, Sabancı University, 2019.

Gürses Söğüt, Sibel. "1912 İshakpaşa Yangını ve Ayasofya Çevresinin Yeniden Düzenlenmesi.” METU Journal of the Faculty of Architecture 36, no. 1 (2019): 251-280.

Gürses Sögüt, Sibel. “Modern Bir İmarı Çözümleme Denemesi: 1865 Hocapaşa Yangını.” Mimarlık Dergisi 56, no. 406 (March/April 2019): 54-60.

Gürsoy, Çiğdem. “Vakfiyelerin Dilinden İstanbul'un Bazı Cami ve Mescitleri Hakkında Yeni Bulgular.” bilig 
- Türk Dünyast Sosyal Bilimler Dergisi 90 (Summer 2019): 161-190.

Güven, Uğur Zeynep. “The Patterns of Participation in the Rebetiko Music Scene of Istanbul.” Journal of Audience and Reception Studies 16, no. 1 (2019): 54-69.

Hammond, Timur. "The Politics of Perspective: Subjects, Exhibits, and Spectacle in Taksim Square, Istanbul." Urban Geography (July 2019). doi.org/10.1080/02723638.2019.1640033.

Hanedar, Avni Önder, et al. "The Ottoman Dissolution and the İstanbul Bourse between War and Peace: A Foreign Exchange Market Perspective on the Great War." Scandinavian Economic History Review 67, no. 2 (2019): 154-170.

Heinz Kaymak, Gamze, and Gül Yücel. "Sustainability, Disaster Risk and Conservation Problems of Industrial Heritages between Yedikule and Küçükçekmece, Istanbul." In Structural Analysis of Historical Constructions, edited by Rafael Aguilar et al., 2035-2043. Cham: Springer International Publishing, 2019.

Heller, Marvin J. "Belvedere and Kuru Tsheshme: Sephardic Printing in Late Sixteenth Century Constantinople." Sephardic Horizons 9, no. 1/2 (2019).

Herzog, Christoph, and Richard Wittmann, eds. Istanbul - Kushta - Constantinople: Narratives of Identity in the Ottoman Capital, 1830-1930. London: Routledge, 2019.

Holmes, Catherine. "De-centring Twelfth-Century Constantinople: Archbishop Eustathios and the Norman Conquest of Thessalonica Revisited." In Byzantium and the West: Perception and Reality (11th-15th c.), edited by Nikolaos Chrissis, Athina Kolia-Dermitzaki, and Angeliki Papageorgiou, 141-155. London: Routledge, 2019.

Horoz, Muhammet Ali. “17. Yüzyıl Başlarında Galata'ya Gelen Ticari Ürünler ve Galata Gümrük Bölgesi.” Anasay 3, no. 7 (February 2019): 137-156.

Hurbanič, Martin. The Avar Siege of Constantinople in 626. Cham: Palgrave Macmillan, 2019.

Ingram, Rebecca. "The Hull of Yenikapı Shipwreck YK 11: A 7th-Century Merchant Vessel from Constantinople's Theodosian Harbour." International Journal of Nautical Archaeology 47, no. 1 (March 2018): 103-139.

Ilikan Rasimoğlu, Ceren Gülser. "Tanzimat, Hayırseverlik ve Kadın: Filles de la charité Rahibelerinin Osmanlı İmparatorluğu Topraklarına Gelişi ve İstanbul'daki İlk Yılları.” Dokuz Eylül Üniversitesi Sosyal Bilimler Enstitüsü Dergisi 20, no. 4 (December 2018): 603-619.

İlyasi, Tahir. İstanbul Hatıratı 1922. İstanbul: Kırmızı Kedi Kitabevi, 2019.

İnalcık, Halil. İstanbul Tarihi Araştırmaları / Fetihten Sonra İstanbul'un Yeniden İnşası - Bilâd-i Selâse : Galata, Eyüp, Üsküdar. İstanbul: Türkiye İş Bankası Kültür Yayınları, 2019.

İnce, Ayça. "Converted Spaces, Converted Meanings: Looking at New Cultural Spaces in Istanbul through a Cultural Policy Lens." In Turkish Cultural Policies in a Global World, edited by Muriel Girard, JeanFrançois Polo, Clemence Scalbert-Yücel, 105-125. Springer International Publishing, 2018.

Janev, Vladimir. “An American Author on the Situation in Istanbul in July 1908." Балканистичен Форум 1 (2018): 118-123.

Kahraman, Cengiz. Hoş Geldin Gazi: Atatürk’ün İstanbul Günleri (1927-1938). İstanbul: Yapı Kredi Yayınları, 2019.

Kahya, G. Yeliz, and Anlı Ataöv. "Cultural Actors as Agents of Generating Social Co-Presences within the Place: Istanbul's Contemporary Art Scene.” European Planning Studies 27, no. 6 (February 2019): 1177-1199.

Kakırman Yıldız, Asiye, Bahattin Yalçınkaya, and Varol Saydam. "An Evaluation of the Eligibility of Public Libraries in Istanbul for Pre-school Period Children.” DTFC Dergisi 58, no. 2 (December 2018): 1811-1836.

Kaldellis, Anthony. Romanland: Ethnicity and Empire in Byzantium. Cambridge: Harvard University Press, 2019.

Kamacı Karahan, Ebru. "Residential Mobility Patterns in Istanbul: 1990-200o." Elektronik Sosyal Bilimler Dergisi 18, no. 70 (April 2019): 466-485.

Kan, Tuna, et al. "Rapid 3D Digitalization of the Cultural Heritage: A Case Study on Istanbul Suleymaniye Social Complex (Kulliye)." The International Archives of the Photogrammetry, Remote Sensing and Spatial Information Sciences, Volume XLII-2/W11 (2019): 645-652.

Kanberoğlu, Nesrin. “II. Meşrutiyet Dönemi İstanbul'da İmar Faaliyetleri (1908-1914).” International Journal of History 11, no. 1 (February 2019): 155-177. 
Kaptanoğu, İpek Zeynep, and Elif Mıhçıŏlu Bilgi. "Conservation of Historic Sarıyer District in Istanbul: Improving the Sustainability and Energy Efficiency of a Bosphorus Village.” Megaron 14, no. 2 (2019): 296-307.

Karaca, Ferhat, Tuğrul Yanık, and Ali Türkyılmaz. "Saving Old Cities: Land Use Regression Model for Traffic Emissions in the Historical Peninsula of Istanbul." International Journal of Global Environmental Issues 18, no. 1 (2019): 24-40.

Karacaoğlu, Emre. "1901 İstanbul Veba Salgını Sırasında İstanbul’a Çağrılan Veba Uzmanlarına Dâir Bir Araştırma." International Journal of History 11, no. 1 (February 2019): 179-201.

Karadayı Yenice, Tülay, and Ülkü Altınoluk. "New Uses for Old Buildings: The Case of 'Soğukçeşme' Street, İstanbul, Turkey." Iconarp International Journal of Architecture and Planning 7, no. 1 (2019): 314-329.

Karakuş, Filiz, Z. Gediz Urak, and Zühal Özcan. "The Historical Water Systems of Istanbul and Their Preservation Problems: The Case of the Kırkçeşme Water System.” Gazi University Journal of Science 31, no. 2 (2018): 368-379.

Kayhan Müldür, Sezen. "Open-Air Cinemas of Istanbul from the 1950 os to Today." Space and Culture 1, no. 16 (September 2018).

Keçici, Zeynep Ceran, and Deniz Mazlum. "İstanbul Davud Paşa Camisi Hakkında Yeni Bir Belge." Mimarlık 408 (July/August 2019): 64-68.

Kentel, K. Mehmet. "Nature's Cosmopolis: Villagers, Engineers, and Animals along Terkos Waterworks in Late Nineteenth-Century Istanbul." In The Seeds of Power: Explorations in the Environmental History of the Ottoman Empire, edited by Onur İnal and Yavuz Köse, 155-183. Winwick: The White Horse Press, 2019. Reviewed in YILLIK: Annual of Istanbul Studies 1 (2019), by Önder Eren Akgül.

Kesimoğlu, Ayşegül. "Modernity and Taste: A Study of Food, Culture and Identity in Istanbul." PhD diss., University of London, 2018.

Kılıç, Abdurrahman. İstanbul Yangın Kuleleri ve Çığırtkanları. İstanbul: Yem Yayın, 2019.

Kırbaş Akyürek, Berrak. "ístanbul'un Kıyılarındaki Yerel Problemler: Maltepe-Kartal Sahili.” Megaron 14, no. 2 (2019): 308-318.

Kısar Koramaz, Elif, Turgay Kerem Koramaz, and Özlem Özer. "Urban Transformation through PropertyLed Regeneration: A Case of Building Renewals in Istanbul." AIZ ITU Journal of the Faculty of Architecture 15, no. 2 (July 2018): 183-196.

Kizıldere, Dicle, and Francesco Chiodelli. "Discrete Emergence of Neoliberal Policies on Public Space: An Informal Business Improvement District in Istanbul, Turkey." Urban Geography 39, no. 5 (2018): $783-802$.

Kocaman, Kasım. "Kuruluş Vakfiyesine Göre İstanbul Fatih Camii Görevlileri ve Vazifeleri." Ekev Akademi Dergisi ICOAEF Özel Sayı (Mart 2019): 135-153.

Koçak, Hakan. “68'de Öğrenci-İşçi Dayanışması: İşçi-Gençlik Elele!” In 1968: Isyan, Devrim, Özgürlük, ed. Ömer Turan, 333-355. İstanbul: Tarih Vakf1 Yurt Yayınlar1, 2019.

Koramaz, Turgay Kerem. "Housing Renewal Sites and Spatial Features of Deterioration and Deprivation in Istanbul's Historic Peninsula." Journal of Urban Planning and Development 144, no. 1 (March 2018).

Korn, Lorenz. "The "German Fountain" in Istanbul: Object of Transfer in the Age of Historicism and Diplomacy." Der Islam 95, no. 2 (October 2018): 549-595.

Kougoulos, Thanasis. "19. Yüzyıl İstanbul Rum Gizem Romanlarına Genel Bir Bakış." Roman Kahramanları 38 (April/June 2019): 66-78.

Kreinath, Jens, and Refika Sariönder. "Dynamics of Ritual Reflexivity in the Alevi Cem of Istanbul." Religion and Society 9, no. 1 (September 2018): 145-159.

Kubat, Ayşe Sema, Ela Akdoğan, and Mert Akay. "Visual Impact Analysis in Urban Morphology: The Case of the Golden Horn, Istanbul." In Proceedings of the XXV ISUF International Conference 'Urban Form and Social Context: from Traditions to Newest Demands,' (Krasnoyarsk, July 5-9, 2018), edited by Irina Kukina, Irina Fedchenko, and Iana Chui, 105-117. Krasnoyarsk: Siberian Federal University Library and Publishing Complex, 2019.

Kurtaran, Uğur. "Karlofça Antlaşması'ndan Sonra İstanbul'a Gelen Yabancı Elçilerin Ağırlanması ve Yapılan Harcamalar.” Ankara Üniversitesi Tarih Araştırmaları Dergisi 37, no. 63 (2018): 331-370.

Küçükali, Ufuk Fatih, and Lütfiye Kuşak. "Environmental, Social, and Economic Indicators of Urban Land Use Conflicts: Evidence from Istanbul Metropolitan Area.” In Urbanization and Its Impact 
on Socio-Economic Growth in Developing Regions, edited by Umar Benna and Indo Benna, 285-308. Hershey: IGI Global, 2018.

Liebelt, Claudia. "Secular Self-Fashioning against 'Islamization': Beauty Practices and the Crafting of Secular Subjectivities among Middle-Class Women in Istanbul." In Secular Bodies, Affects and Emotions: European Configurations, edited by Monique Scheer, Nadia Fadil, Johansen Schepelern Birgitte, 109-122. London: Bloomsbury Academic, 2019.

Lougheed, Christopher. "Gregory of Nazianzus and Q. Aurelius Symmachus: The Conflict between East and West and Elite Self-Presentation in the Later Fourth Century AD Rome and Constantinople." Mouseion: Journal of the Classical Association of Canada 16, no. 1 (2019): 121-143.

Magdalino, Paul. "Constantinople in the Age of Constantine VII Porphyrogennetos: Life at the Center." In Center, Province and Periphery in the Age of Constantine VII Porphyrogennetos: From De ceremoniis to De administrando imperio, edited by Niels Gaul, Volker Menze and Csanád Bálint. 39-54. Wiesbaden: Harrassowitz Verlag, 2018.

Markopoulos, Athanasios. "Voices from the Center: Constantine VII Porphyrogennetos and the Macedonian Dynasty in Contemporary Historiography. With an Appendix: Three Letters from Romilly J. H. Jenkins to Gyula Moravcsik." In Center, Province and Periphery in the Age of Constantine VII Porphyrogennetos: From De ceremoniis to De administrando imperio, edited by Niels Gaul, Volker Menze and Csanád Bálint. 22-38. Wiesbaden: Harrassowitz Verlag, 2018.

Masoumi, Houshmand E., Fatih Terzi, and Yehya M. Serag. "Neighborhood-Scale Urban Form Typologies of Large Metropolitan Areas: Observations on Istanbul, Cairo, and Tehran." Cities 85 (February 2019): 170-186.

Melvani, Nicholas. "Late, Middle, and Early Byzantine Sculpture in Palaiologan Constantinople." In Spolia Reincarnated: Afterlives of Objects, Materials, and Spaces in Anatolia from Antiquity to the Ottoman Era, edited by Ivana Jevtić and Suzan Yalman, 149-172. Istanbul: ANAMED, 2018. Reviewed in YILLIK: Annual of Istanbul Studies 1 (2019), by Emily Neumeier.

Memiş, Mehmet, and Neziha Bezci. "Arşiv Belgeleri Bağlamında Emirgan/Mirgün Hamid-i Evvel Camiinin Tarihi ve Mimari Özellikleri.” Sosyal ve Kültürel Araştırmalar Dergisi 5, no. 9 (2019): 61-103.

Mills, Amy. "Becoming Blind to the Landscape: Turkification and the Precarious National Future in Occupied Istanbul." Journal of the Ottoman and Turkish Studies Association 5, no. 2 (Fall 2018): 99-117.

Mutman, Demet, and Hülya Turgut. "Colliding Urban Transformation Process: The Case of Historical Peninsula, Istanbul.” ArchNet-iJAR 12, no. 1 (2018): 164-181.

Okay, Yeliz. "Traveling to Istanbul's Social Memory with regard to Lost Daily Life with Istanbul's Epics: Reşat Ekrem Koçu and Istanbul Encyclopedia." Turcologia 14, no. 27 (Spring 2019): 56-64.

Olley, Jacob. "Writing Music in Nineteenth-Century Istanbul: Ottoman Armenians and the Invention of Hampartsum Notation.” PhD diss., King's College London, 2018.

Orlandi, Luca. "Traveler's Descriptions of Vernacular Architecture in Istanbul, Turkey (15th - 19th Century).” ISVS e-journal 5, no. 2 (June 2018).

Ousterhout, Robert. "Constructing and Deconstructing Sacred Space in Byzantine Constantinople." In Sacred Spaces and Urban Networks, edited by Suzan Yalman and Hilâl Uğurlu, 89-104. Istanbul: ANAMED, 2019.

Öner, Onur. "A Collective Biography Study of Musicians: Patterns, Networks and Music as a "Profession" in the Late Ottoman Era and the Early Republican Years in Istanbul.” PhD diss., İstanbul Şehir University, 2019.

Öz, Özlem, and Mine Eder. "'Problem Spaces' and Struggles over the Right to the City: Challenges of Living Differentially in a Gentrifying Istanbul Neighborhood." International Journal of Urban and Regional Research 42, no. 6 (November 2018): 1030-1047.

Özdüzen, Özge. "Spaces of Hope in Authoritarian Turkey: Istanbul's Interconnected Geographies of Post-Occupy Activism.” Political Geography 70 (April 2019): 34-43.

Özeren, Deniz. "The Dirt of Istanbul: Coping with Pollution in the 19th Century." MA thesis, Middle East Technical University, 2019.

Özger, Yunus. “1894 İstanbul Depreminde İzmit'te Afet ve Kriz Yönetimi.” Türkiyat Araştırmaları Enstitüsü Dergisi 65 (May 2019): 333-346.

Özkan, Nevin. "The Moments of Italian Presence in Constantinople - Istanbul." Studia Polensia 7, no. 
Özkan, Özgür. "Istanbul; the Outgrowing City." Online Journal of Art \& Design 6, no. 5 (December 2018): 205-222.

Özkaya, Hatice Gökçen. "Living Conditions in Houses of Istanbul during the 17th Century: A Reading of Kadı Registries.” Turkish Academy of Sciences Journal of Cultural Inventory 19 (2019): 75-88.

. "Osmanlı Evleri Üzerine Yeniden Düşünmek: 18. Yüzyıldan Dahiliyeli-Hariciyeli Beş İstanbul Evi Örneği.” METU Journal of the Faculty of Architecture 35, no. 1 (2018): 243-262.

Özpınar, Ceren. "The Istanbul Biennial and the Reproduction of the Urban Public Space.” Art \& the Public Sphere 7, no. 1 (July 2018): 7-23.

Özsait-Kocabaş, Iş1l. "The Yenikap1 12 Shipwreck, a 9th-Century Merchantman from the Theodosian Harbour in Istanbul, Turkey: Construction and Reconstruction." International Journal of Nautical Archaeology 47, no. 2 (2018): 357-390.

Öztürk, Ali İhsan. Başlangıçtan Bugüne İstanbul’un Belediyeleri. İstanbul: İdeal Kültür Yayıncıllk, 2019.

—. Istanbul Şehir Suyu Hizmetinde Şirketler Dönemi (1881-1937). İstanbul: İdeal Kültür Yayınc1lık, 2019.

Öztürk, Tahir. "Enderunlu Vâsıf Divanı'nda İstanbul ve İstanbul Yaşantısı.” MA thesis, Çă̆ Üniversitesi, 2019.

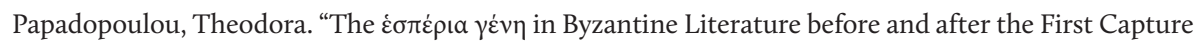
of Constantinople (Mid-12th to Mid-13th c.)" In Byzantium and the West: Perception and Reality (11th15th c.), edited by Nikolaos Chrissis, et al., 245-256. London: Routledge, 2019.

Pehlivan, Burcu. "1914 Kuşağı Sanatçılarının Resimlerinde İstanbul İzleği (Teması)." Dumlupınar Üniversitesi Sosyal Bilimler Dergisi, Özel Sayı (March 2019): 100-118.

Pinon, Pierre. Les Villes et Les Maisons Ottomanes. Istanbul: The Isis Press, 2019.

Pitarakis, Brigitte. "The Ritual of the Blessing of the Waters and Copper Alloy Vessels." Istanbul Araştırmaları Yullığı 7 (2018): 31-48.

Pugsley, David. “Justinian's Welcome to the Constantinople Law School.” Fundamina 24, no. 1 (2018): 57-68.

Ramsay, William Mitchell. İsyan Günlerinde İstanbul. Bir İngiliz Arkeoloğun Gözünden 31 Mart İsyanı. İstanbul: Timaş Yayınları, 2019.

Reis Eken, Sümeyye. "Two Worlds Meeting in One Neighborhood: Receiving Society Members-Afghan Workers Relations in Yenimahalle, Istanbul.” MA thesis, Sabancı University, 2019.

Rezafar, Azadeh, and Şevkiye Sence Türk. "Urban Design Factors Involved in the Aesthetic Assessment of Newly Built Environments and Their Incorporation into Legislation: The Case of Istanbul." Urbani Izziv 29, no. 2 (December 2018): 83-95.

Ricci, Alessandra. "Maneviyat, Geçim ve Ticaret: Orta ve Geç Bizans Döneminde Satyros Manastırı (Küçükyal1, İstanbul).” Arkeoloji ve Sanat 16o (January-April 2019): 129-140.

Roelcke, Annegret. "Constructing the 'Capital of Peace': Changing Branding Strategies for Istanbul's Eyüp Quarter.” Middle East - Topics \& Arguments 12, no. 1 (June 2019): 110-112.

Ruggeri, Francesca. "Engineering the Byzantine Water Supply of Constantinople: Mapping, Hydrology and Hydraulics of the Long Aqueducts Outside the City." PhD diss., University of Edinburgh, 2018.

Rüstem, Ünver. Ottoman Baroque: The Architectural Refashioning of Eighteenth-Century Istanbul. Princeton: Princeton University Press, 2019.

_ . "Spolia and the Invocation of History in Eighteenth-Century." In Spolia Reincarnated: Afterlives of Objects, Materials, and Spaces in Anatolia from Antiquity to the Ottoman Era, edited by Ivana Jevtić and Suzan Yalman, 289-308. Istanbul: ANAMED, 2018. Reviewed in YILLIK: Annual of Istanbul Studies 1 (2019), by Emily Neumeier.

Sabancı, Zeynep Güler. "Alman İktisadi Teşebbüsleri ve I. Dünya Savaşı'nda İstinye Mühimmat Fabrikasının Durumu.” İstanbul Araştırmaları Yıllığı 7 (2018): 171-174.

Salbacak, Salih. "Mütareke Dönemi İstanbul'unda Beyoğlu'nun Çok Kültürlü Yapısı ve Frej Apartmanı.” International Journal of Social and Humanities Sciences 3, no. 1 (2019): 33-44

Sande, Siri. “"The Horrible Lady” in Istanbul: Is a Public Non-imperial Female Portrait Possible in the Sixth Century AD?" Acta ad archaeologiam et artium historiam pertinentia 30 (2018): 169-187.

Sarınay, Yusuf. “Türkistanlı Hacıların Ziyaret Merkezi Olarak İstanbul.” bilig - Türk Dünyası Sosyal Bilimler Dergisi 88 (2019): 1-18.

Savage, Matthew. "Building Heavenly Jerusalem: Thoughts on Imperial and Aristocratic Construction 
in Constantinople in the 9th and 1oth Centuries." In Byzantium in Dialogue with the Mediterranean, edited by Daniëlle Slootjes, Mariette Verhoeven, 67-90. Leiden: Brill, 2019.

Schoon, Danielle V., and Funda Oral. "The Role of Communities of Practice in Urban Rights Activism in Istanbul, Turkey." In Global Sustainability and Communities of Practice, edited by Carl A. Maida, Sam Beck, 94-108. New York, Oxford: Berghahn Books, 2018.

Seçkin Çetinkaya, Bilge. “Devrim için Hareket, Hareket için Tiyatro: 1968'de Sokaklar, Iş̧̧̧iler ve Gençler.” In 1968: İsyan, Devrim, Özgürlük, ed. Ömer Turan, 549-560. İstanbul: Tarih Vakf1 Yurt Yayınlar1, 2019.

Selcen Coşkun, Burcu. “Türkiye'de Anıtsal Yapıların Korunmasında Uygulama Boyutunda Yaşanan Sorunlar: Ayasofya Müzesi ve Fatih Camii Örnekleri.” Sanat Tarihi Dergisi 28, no. 1 (April 2019): 39-65. Seyfeli, Canan. İstanbul Ermeni Patrikliği Kuruluşu ve İdari Yapısı. İstanbul: Çizgi Kitabevi, 2019.

Sezer Aydınlı, Elif. "Unusual Readers in Early Modern Istanbul. Manuscript Notes of Janissaries and Other Riff-Raff on Popular Heroic Narratives." Journal of Islamic Manuscripts 9 (2018): 109-131.

Siu, leong, et al. "An Archaeological and Chemical Investigation of 11th-12th Centuries AD Glasses from Zeyrek Camii (the Pantokrator Church) in Byzantine Constantinople." Archaeological and Anthropological Sciences 11, no. 6 (June 2019): 2637-2647.

Soğuk, Olcay. Efsane Vali: İstanbul Valisi Dr. Lütfi Kırdar'ın Yaşam Öyküsü. İstanbul: Doğan Kitap, 2019. Sönmez, Özdemir. “istanbul Metropoliten Alan Planlamasında Uygulama Güçlükleri: Kartal Dönüşüm Projesi Deneğimi." Megaron 13, no. 3 (2018): 407-421.

Suciyan, Talin. Modern Türkiye'de Ermeniler: Soykırımsonrası Toplum, Siyaset ve Tarih. Çeviren Ayşe Günaysu. İstanbul: Aras Yayıncılık, 2018.

Sullu, Bengi. "Geographies of Children's Play in the Context of Neoliberal Restructuring in Istanbul.*" Children's Geographies 16, no. 2 (2018): 169-183.

Suman, F. Selva. "The Silent City: Reading TOMB Structures at the Latin Catholic Cemetery in Feriköy, İstanbul." PhD diss., Istanbul Technical University, 2019.

Şahin, Öznur. "From Home to City: Gender Segregation, Homosociality and Publicness in Istanbul." Gender, Place and Culture 25, no. 5 (2018): 743-757.

Şekeryan, Ari. "The Transformation of the Political Position of the Armenian Community in Istanbul vis-à-vis the Declaration of the Republic of Turkey." Turkish Studies (2019). doi.org/10.1080/14683 849.2019.1604137

Şenşar, Dilara. "Hayalet Kentsel Mekânlar: İstanbul Üzerinden Bir Okuma.” MA thesis, Maltepe University, 2019.

Şevki, Orhan. Osmanlı'dan Cumhuriyet'e: Azınlık Spor Kulüpleri ve Sporcular. İstanbul: Türkiye İş Bankası Kültür Yayınları, 2018.

Tak, Ekrem, and Bilgin Aydın. "XVII. Yüzyılda İstanbul Medreselerinde Okutulan Kitaplar (Tereke Kayıtları Üzerine Bir Değerlendirme).” Dil ve Edebiyat Araştırmaları 19 (Spring 2019): 183-236.

Tanman, M. Baha. "Osmanlı Bahçe Tasarımında Unutulmuş Bir Ayrıntı: Bahçe Duvarı Kafesleri ve Panjurları.” Istanbul Araştırmaları Yıllığı 7 (2018): 133-136.

Tanülkü, Başak. "The Formation and Perception of Safety, Danger and Insecurity Inside Gated Communities: Two Cases from Istanbul, Turkey." Journal of Housing and the Built Environment 33, no. 1 (March 2018): 151-173.

Tanyeli, Uğur. "Spatiality of the Rebellions: The Female Rebels of Istanbul and the Architectures of Discontent (1730-1908)." Istanbul Araştırmaları Yıllı̆̆ı 7 (2018): 147-158.

Taranto, Mirco, et al. "The Bricks of Hagia Sophia (Istanbul, Turkey): A New Hypothesis to Explain Their Compositional Difference." Journal of Cultural Heritage 38 (July 2019): 136-146.

Tarçın Turgay, Zeynep. "Reviewing Istanbul's Urban Structure through a Local Retail Shop: Neco Cornet Ice Cream Shop." AIZ ITU Journal of the Faculty of Architecture 15, no. 2 (July 2018): 39-50.

Tchilingirian, Hratch. Ermeni Kilisesi: Tarih, İnanç, Litürji, Sakramentler ve Hiyerarşiye Kısa Bir Giriş. Çeviren Lora Sarı. İstanbul: Aras Yayıncilık, 2019.

Tellioğlu Şeren, Tuba. "An Evaluation of the Impacts of Culture-Led Industrial Heritage Regeneration Projects in İstanbul.” MA thesis, İstanbul Bilgi University, 2019.

Temizgüney, Firdes. "1960 Darbesine Giden Süreçte Önemli Bir Kesit: İstanbul Öğrenci Olayları.” Cumhuriyet Tarihi Araştırmaları Dergisi 14, no. 27 (Spring 2018): 181-211.

Toprak, Zafer. "1968-1969 İstanbul Üniversitesi Boykot ve İşgalleri.” In 1968: İsyan, Devrim, Özgürlük, 
edited by Ömer Turan, 247-273. Istanbul: Tarih Vakfı Yurt Yayınları, 2019.

Torun, Perihan, et al. "Health and Health Care Access for Syrian Refugees Living in İstanbul." International Journal of Public Health 63, no. 5 (June 2018): 601-608.

Trudinger, David. "The View from Constantinople, 1915: The Australian, the Ambassador and the Agent on Gallipoli and the Armenian Genocide." History Australia 15, no. 4 (2018): 725-743.

Türken, Hazal. “The Role of Street Art in State-Led Gentrification: Case Study on Mural Istanbul.” MA thesis, University of Jyväskylä, 2019.

Türkmen, Zekeriya. "Mütareke ve İşgal Döneminde Kamuoyu Oluşturma Çabaları Bağlamında İstanbul Mitingleri Üzerine Bir Değerlendirme.” In Yeditepe Üniversitesi Tarih Bölümü I. Uluslararası Türk Kültürü ve Tarihi Sempozyumu (18-21 Nisan 2018) Bildiri Kitabl, edited by Ahmet Taşağıl et al., 265-291. İstanbul: Yeditepe Üniversitesi Yayınevi, 2019.

Türkoğlu, Handan, et al. "Residential Satisfaction in Formal and Informal Neighborhoods: The Case of Istanbul, Turkey." International Journal of Architectural Research 13, no. 1 (2019): 112-132.

Uçar, Zeynep. İstanbul Çorlulu Ali Paşa Külliyesi Mezar Taşları. Istanbul: Yalın Yayıncılık, 2019.

Uğur, Yunus, ed. İstanbul Türbe, Hazire ve Kabirleri. İstanbul: IBBB Kültür AŞ, 2019.

Uğurlu, Hilâl. "The Role of "Sacreds" in the Political Agenda of the "Reformist" Ottoman Sultan Selim IIl (r. 1789-1807)." In Sacred Spaces and Urban Networks, edited by Suzan Yalman and Hilâl Uğurlu, 105-118. Istanbul: ANAMED, 2019.

Uğurlu, Kaplan, and Erencan Çekiç “"Şehir Hakkı ve Turizm: İstanbul Üzerine Ampirik Bir Çalışma.” Journal of Tourism and Gastronomy Studies 7, no. 1(2019): 286-309.

Utkugün, Ceren, and Şaban Ortak. "Ekim Seferberliği Kapsamında 1942 Yılında İstanbul ve Ankara'da Bahçe Ziraati Uygulamaları." Cumhuriyet Tarihi Araştırmaları Dergisi 15, no. 29 (Spring 2019): 373-404.

Uzelac, Aleksandar. "Cumans in the Latin Empire of Constantinople." Zolotoordynskoe Obozrenie 7, no. 1 (2019): 8-21.

Ünveren, Burak, and Kazım Baycar. "Historical Evidence for Anchoring Bias: The 1875 Cadastral Survey in Istanbul." Journal of Economic Psychology 73 (August 2019): 1-14.

Üstünipek, Şeyda. "Formation of the Collection of the Foreign Artists during the Establishment of Istanbul Painting and Sculpture Collection." The Turkish Online Journal of Design, Art and Communication 9, no. 2 (April 2019): 292-302

Vaiou, Maria. "The Byzantine Churches of Constantinople After the Fall.” Journal of Religious Culture 245 (2019): 1-20.

Van Tricht, Filip. The Horoscope of Emperor Baldwin II: Political and Sociocultural Dynamics in LatinByzantine Constantinople. Leiden: Brill, 2018.

Villeneuve, Louis S. Les Rapports de Louis-Sauveur, Marquis de Villeneuve, Ambassadeur du Roi de France, Auprès de La Sublime Porte Ottomane (1728-1741). Edited by Sinan Kuneralp. Istanbul: Les éditions ISIS, 2019.

Ward, Kate Alice. "Engineering Exploration of the Water Supply System of Constantinople," PhD diss., University of Edinburgh, 2018.

Yalçın, M. Namık, et al. "Establishing a High-Resolution Stratigraphy in the Holocene Marine Sequence of the Ancient Theodosian Harbor of Istanbul with the Help of Dendrochronology." Geoarchaeology 34, no. 3 (May/June 2019): 360-374.

Yapıc1, Mücella, and Esin İleri. “Urban Transformation in Istanbul." In Authoritarianism and Resistance in Turkey, edited by Esra Özyürek, Gaye Özpınar, and Emrah Altındiş, 63-71. Cham: Springer International Publishing, 2019.

Yaşar, Zeynep. “'Emek Is Ours, Istanbul Is Ours': Reimagining a Movie Theater through Urban Activism.” The Velvet Light Trap 83 (Spring 2019): 46-59.

Yavuz, Seda. "Belkıs Mustafa: 'Sanat Uzun, Hayat Kısa.” İstanbul Araştırmaları Yıllığı 7 (2018): 175-18o.

Yazar, Nadide Ebru, and Can Şakir Binan. "Haydarpaşa İstasyonu Dairesel Planlı Lokomotif Deposu'nun Koruma Olasilikları.” Megaron 14, no. 2 (2019): 254-268.

Yetişkul, Emine, and Şule Demirel. "Assembling Gentrification in Istanbul: The Cihangir Neighbourhood of Beyoğlu." Urban Studies 55, no. 15 (November 2018): 3336-3352.

Yıldız, Güllü. "Gardens of Istanbul in Persian Hajj Travelogues." In Travellers in Ottoman Lands: The Botanical Legacy, edited by Ines Aščerić-Todd, Sabina Knees, Janet Starkey and Paul Starkey, 57-68. 
Oxford: ASTENE and Archaeopress Publishing, 2018.

Yılmaz, Müslüm. “ístanbul'da Levanten Bir Ressam: Lazar Binenbaum.” Art-Sanat 10 (July 2018): 328-345. Yiğit Turan, Burcu. "Revitalizing the Yeldegirmeni Neighbourhood in Istanbul: Towards an Emancipatory Urban Design in the Landscapes of Neoliberal Urbanism." In Public Space Unbound, edited by Sabine Knierbein and Tihomir Viderman, 158-172. New York: Routledge, 2018.

Yoncacı Arslan, Pelin. "Registrars of Urban Movement in Constantinople: Monumental Columns and the Mese." Istanbul Araştırmaları Yıllı̆̆ı 7 (2018): 7-30.

Yonucu, Deniz. "Urban Vigilantism: A Study of Anti-Terror Law, Politics and Policing in Istanbul." International Journal of Urban and Regional Research 42, no. 3 (May 2018): 408-422.

Yücel, Hakan. “Günümüz Türkiye’sinde Ermeni Genci Olmak: İstanbul'daki Ermeni Liseleri Mezunu Gençlerin Kimlik Algıları, Kimlik Kaynakları ve Kimlik Stratejileri.” Alternatif Politika 11, no. 2 (June 2019): 401-429. 